\title{
THE SUMMER MEETING IN CAMBRIDGE
}

The forty-second Summer Meeting of the Society and the nineteenth Colloquium were held at Harvard University, Cambridge, Massachusetts, in connection with the Harvard Tercentenary Conference of Arts and Sciences, from Monday, August 31 to Saturday, September 5. This was the fourth meeting of the Society to be held in Cambridge. It was the second Summer Meeting held there, the earlier one having been in September, 1916. The other two meetings were held in conjunction with the American Association for the Advancement of Science in December, 1922, and in December, 1933, the Massachusetts Institute of Technology then participating as one of the hosts.

Harvard University, celebrating its Tercentenary, was a gracious host, and hospitality was unbounded. All lectures given during the week under the auspices of the Tercentenary Committee were open to the mathematicians. More than half of those attending were housed without charge in the Yard. There were a large number of excursions and social diversions. All the facilities of the University were at the disposal of the visitors, who were unanimous in praise of the arrangements made for their comfort and convenience. At the Saturday morning session the following resolution was adopted by standing vote:

Resolved: that we, the members of the American Mathematical Society and the Mathematical Association of America, here assembled for the largest meeting in the history of our organizations, express our profound appreciation to the President and Fellows of Harvard College and to the Tercentenary Committee for sharing with us the distinguished guests of the Tercentenary Conference and for the most generous provision which they have made for us in the buildings of Harvard University; to Mr. Greene, Mr. Land, and Mr. McNeil of the Tercentenary Committee for the painstaking attention which they have given to our comfort and convenience; to the Division of Mathematics and the Committee on Arrangements, including especially Dean and Mrs. Birkhoff and Professor and Mrs. Graustein, for the extraordinary care with which they have provided for our sessions and our entertainment and for the exhibition of notable mathematical books and of the work of the Division; and to the ladies of the Division of Mathematics, to President McAfee and Professor Young of Wellesley College, and to Professor and Mrs. Shapley for their gracious hospitality. 
The Mathematical Association of America, the Institute of Mathematical Statistics, the Association for Symbolic Logic, and the American Astronomical Society held sessions during the same week. Among the more than one thousand persons attending the meetings arranged by the Society, approximately eight hundred registered, of whom 443 are members of the Society. This constitutes a record attendance, an excess of fifty per cent more than at the largest meeting hitherto. Among the members of the Society present, there were forty-one states represented, and five provinces of Canada, besides Europe and Asia. The largest delegation (76) was from Massachusetts, followed by New York (72), Pennsylvania (34), New Jersey (31), Ohio (23), Illinois (21), Rhode Island (18), Michigan (17), Connecticut (13).

The following members of the Society were in attendance:

C. R. Adams, R. B. Adams, V. W. Adkisson, C. F. Adler, H. L. Agard, R. P. Agnew, E. B. Allen, C. B. Allendoerfer, R. C. Archibald, R. G. Archibald, L. A. Aroian, W. L. Ayres, R. W. Babcock, C. L. Bacon, H. M. Bacon, Reinhold Baer, D. H. Ballou, G. M. Bareis, J. L. Barnes, I. A. Barnett, J. H. Bartlett, Ralph Beatley, Samuel Beatty, M. F. Becker, E. R. Beckwith, R. D. Beetle, A. A. Bennett, D. L. Bernstein, Felix Bernstein, Garrett Birkhoff, G. D. Birkhoff, Gertrude Blanch, H. F. Blichfeldt, G. A. Bliss, R. P. Boas, H. F. Bohnenblust, J. W. Bower, M. G. Boyce, C. B. Boyer, J. W. Bradshaw, Richard Brauer, R. W. Brink, H. W. Brinkmann, Samuel Bronstein, B. H. Brown, B. L. Brown, E. P. Brown, E. W. Brown, O. E. Brown, T. H. Brown, R. E. Bruce, G. S. Bruton, N. R. Bryan, H. E. Buchanan, W. M. Bullitt, L. H. Bunyan, R. S. Burington, F. W. Burton, Jewell H. Bushey, J. H. Bushey, W. H. Bussey, S. S. Cairns, W. D. Cairns, R. H. Cameron, B. H. Camp, A. D. Campbell, G. A. Campbell, M. E. Carlen, F. E. Carr, E. J. Cartan, W. B. Carver, E. W. Chittenden, Alonzo Church, R. N. Cobb, A. B. Coble, Abraham Cohen, L. W. Cohen, Nancy Cole, J. B. Coleman, Esther Comegys, E. G. H. Comfort, H. R. Cooley, J. L. Coolidge, G. A. Coon, T. F. Cope, A. H. Copeland, Byron Cosby, Richard Courant, Carleton Craig, C. C. Craig, A. R. Crathorne, W. L. Crum, C. H. Currier, H. B. Curry, D. R. Curtiss, J. H. Curtiss, E. H. Cutler, D. R. Davis, W. M. Davis, F. F. Decker, W. W. Denton, L. E. Dickson, Vincent Dillon, C. E. Dimick, L. L. Dines, E. C. Doak, J. L. Doob, R. D. Douglass, T. L. Downs, Arnold Dresden, D. M. Dribin, Nelson Dunford, J. C. Durand, W. L. Duren, W. H. Durfee, J. M. Earl, W. W. Elliott, G. C. Evans, G. W. Evans, H. S. Everett, Fay Farnum, Peter Field, T. S. Fiske, W. B. Fite, D. A. Flanders, M. M. Flood, L. R. Ford, Tomlinson Fort, I. G. Foster, R. M. Foster, J. S. Frame, C. W. Franklin, Philip Franklin, A. H. Frink, Orrin Frink, T. C. Fry, D. L. Fuller, A. S. Galbraith, A. S. Gale, C. A. Garabedian, H. L. Garabedian, H. J. Gay, J. J. Gergen, B. C. Getchell, K. S. Ghent, J. L. Gibson, Lachlan Gilchrist, R. E. Gilman, Michael Goldberg, S. H. Gould, A. A. Grant, M. C. Graustein, W. C. Graustein, L. M. Graves, L. W. Griffiths, V. G. Grove, H. V. Gummere, Marshall Hall, 
Harris Hancock, G. H. Hardy, J. G. Hardy, R. A. Harrison, G. G. Harvey, T. W. Hatcher, Alan Hazeltine, G. A. Hedlund, E. R. Hedrick, C. B. Hennel, Max Herzberger, D. M. Hickey, H. C. Hicks, A. O. Hickson, E. H. C. Hildebrandt, T. H. Hildebrandt, R. C. Hildner, Einar Hille, F. H. Hodge, T. F. Holgate, T. R. Hollcroft, Eberhard Hopf, Charles Hopkins, L. A. Hopkins, E. M. Hull, E. V. Huntington, C. A. Hutchinson, M. H. Ingraham, Dunham Jackson, R. F. Jackson, R. L. Jeffery, E. D. Jenkins, Evan Johnson, M. M. Johnson, R. A. Johnson, R. P. Johnson, F. E. Johnston, B. W. Jones, H. E. Jordan, M. L. Kales, L. C. Karpinski, Edward Kasner, L. O. Kattsoff, D. E. Kearney, A. J. Kempner, L. S. Kennison, G. S. Ketchum, P. W. Ketchum, S. H. Kimball, H. R. Kingston, A. D. Kinsman, S. C. Kleene, J. R. Kline, B. O. Koopman, R. L. Korgen, A. C. Ladner, A. W. Landers, M. K. Landers, A. E. Landry, Otto Laporte, E. Kramer Lassar, V. V. Latshaw, V. S. Lawrence, D. H. Leavens, Solomon Lefschetz, A. M. M. Lehr, D. D. Leib, Walter Leighton, F. E. LeStourgeon, Tullio Levi-Civita, Harry Levy, F. P. Lewis, H. G. Lieber, L. R. Lieber, P. H. Linehan, G. H. Ling, Marie Litzinger, W. R. Longley, L. L. Lowenstein, E. D. McCarthy, R. B. McClenon, Dorothy McCoy, N. H. McCoy, E. A. McDougle, W. H. McEwen, J. C. C. McKinsey, Saunders MacLane, H. M. MacNeille, H. F. MacNeish, H. P. Manning, R. J. Marcou, Morris Marden, R. S. Martin, W. T. Martin, R. G. Mason, T. E. Mason, S. P. Mead, A. E. Meder, H. A. Merrill, G. M. Merriman, A. D. Michal, F. F. Middleswart, D. C. Miller, W. I. Miller, E. B. Mode, Deane Montgomery, C. N. Moore, E. M. Morenus, R. K. Morley, Max Morris, Richard Morris, D. S. Morse, Z. I. Mosesson, T. A. Mossman, E. J. Moulton, F. D. Murnaghan, S. B. Myers, J. H. Neelley, C. A. Nelson, John von Neumann, A. V. Newton, R. E. O'Connor, W. F. Osgood, F. W. Owens, H. B. Owens, J. C. Oxtoby, Gordon Pall, W. O. Pennell, W. F. Penney, F. W. Perkins, R. M. Peters, H. B. Phillips, A. E. Pitcher, Hillel Poritsky, E. C. Pousland, G. B. Price, H. A. Rademacher, Tibor Radó, G. Y. Rainich, W. C. Randels, J. F. Randolph, W. R. Ransom, H. W. Reddick, C. J. Rees, W. T. Reid, C. N. Reynolds, Harris Rice, A. V. Richardson, R. G. D. Richardson, C. A. Richmond, D. E. Richmond, H. L. Rietz, David Rines, John Riordan, J. F. Ritt, H. P. Robertson, R. M. Robinson, Robin Robinson, S. L. Robinson, W. B. Robinson, W. H. Roever, R. E. Root, J. B. Rosenbach, J. B. Rosser, N. N. Royall, H. A. Ruger, E. C. Rusk, W. J. Rusk, H. G. Russell, W. M. Rust, George Rutledge, N. E. Rutt, O. K. Sagen, George Sauté, A. C. Schaeffer, S. A. Schelkunoff, I. J. Schoenberg, H. E. Schoonmaker, Wladimir Seidel, I. M. Sheffer, J. A. Shohat, L. L. Silverman, W. G. Simon, T. M. Simpson, E. R. Sleight, M. M. Slotnick, C. H. Smiley, H. L. Smith, T. L. Smith, W. M. Smith, E. S. Sokolnikoff, I. S. Sokolnikoff, Joseph Spear, V. E. Spencer, A. A. Stafford, G. W. Starcher, M. E. Stark, E. P. Starke, R. C. Stauffer, J. Y. Stephens, R. C. Stephens, R. W. Stokes, M. H. Stone, R. B. Stone, W. T. Stratton, R. E. Street, D. J. Struik, R. R. Struik, M. C. Suffa, M. M. Sullivan, Elijah Swift, Gabriel Szegö, J. D. Tamarkin, A. E. Taylor, J. H. Taylor, J. S. Taylor, M. E. Taylor, W. C. Taylor, J. M. Thomas, T. Y. Thomas, Helen Thompson, H. S. Thurston, C. C. Torrance, M. M. Torrey, J. I. Tracey, J. C. Trainor, W. J. Trjitzinsky, A. W. Tucker, C. B. Tucker, J. W. Tukey, H. L. Turrittin, H. W. Tyler, F. E. Ulrich, J. L. Vander- 
slice, J. H. Van Vleck, T. Vijayaraghavan, G. P. Wadsworth, G. W. Walker, R. J. Walker, H. S. Wall, J. L. Walsh, R. M. Walter, T. O. Walton, L. E. Ward, Morgan Ward, J. F. Wardwell, W. G. Warnock, S. E. Warschawski, C. W. Watkeys, Warren Weaver, D. W. Weeks, F. M. Weida, E. T. Welmers, Albert Wertheimer, A. H. Wheeler, O. L. Wheeler, H. S. White, M. B. White, E. A. Whitman, Hassler Whitney, J. K. Whittemore, G. T. Whyburn, D. V. Widder, Norbert Wiener, E. P. Wiggin, E. P. Wigner, C. E. Wilder, R. L. Wilder, S. S. Wilks, Ruby Willis, E. B. Wilson, E. W. Wilson, R. M. Winger, Clement Winston, E. E. Witmer, L. A. Wolf, M. C. Wolf, F. S. Woods, F. M. Wright, B. F. Yanney, C. H. Yeaton, M. M. Young, E. I. Yowell, Oscar Zariski, S. D. Zeldin.

One of the chief features of the meeting was the Series of Harvard Tercentenary Conference Lectures delivered by eminent mathematicians, both foreign and American, whom Harvard University had invited as speakers. These were delivered in the New Lecture Hall and were all broadcast on both long and short wave. The following is a list of these addresses delivered by the courtesy of Harvard University before the Society:

I. Monday afternoon. Uncertain inference. By Ronald Aylmer Fisher, Sc.D., Professor of Eugenics, University of London.

II. Monday evening. The Indian mathematician, Ramanujan. By Godfrey Harold Hardy, D.Sc., LL.D., D.Phil., Professor of Mathematics, University of Cambridge.

III. Tuesday morning. Truth in mathematics and logic. By Rudolf Carnap, D.Phil., Professor of Philosophy, Deutsche Universität, Prague.

IV. Tuesday afternoon. L'extension $d u$ calcul tensoriel aux géométries non-affines. By Élie Joseph Cartan, D.Sc., Professor of Mathematics, University of Paris.

V. Wednesday morning. Waring's problem and its generalizations. By Leonard Eugene Dickson, Ph.D., Professor of Mathematics, University of Chicago.

VI. Thursday morning. The mathematical work of Ramanujan. By Godfrey Harold Hardy, D.Sc., LL.D., D.Phil., Professor of Mathematics, University of Cambridge.

VII. Friday morning. The relativistic problem of several bodies. By Tullio Levi-Civita, Dr.Math., D.Sc., Professor of Rational Mechanics, University of Rome.

VIII. Friday afternoon. Astronomical consequences of the relativistic two-body problem. By Tullio Levi-Civita, Dr.Math., D.Sc., Professor of Rational Mechanics, University of Rome. 
IX. Friday afternoon. The cosmical constant and the recession of the nebulae. By Sir Arthur Stanley Eddington, Sc.D., LL.D., Professor of Astronomy, University of Cambridge.

Lecture I was delivered before a joint session with the Mathematical Association of America and the Institute of Mathematical Statistics at which Professor H. L. Rietz presided; II before a joint session with the M.A.A., Professor J. L. Coolidge presiding; III before a joint session with the Association for Symbolic Logic, a sectional meeting which was arranged by Professor H. B. Curry and presided over by Professor A. A. Bennett. C. J. Ducasse, Professor of Philosophy at Brown University, introduced Professor Carnap. There were 350 persons at this session and 50 attended a special luncheon immediately following at the Faculty Club at which Professor A. N. Whitehead gave an hour address, Professor E. V. Huntington presiding. Professor H. S. White presided at Lecture IV, Professor A. B. Coble at V, Professor T. S. Fiske at VI, Professor E. W. Brown at VII. Lectures VIII and IX were given before a joint session with the American Astronomical Society, Dean G. D. Birkhoff presiding; and these were followed by discussion on the part of Professor Arthur Haas of the University of Vienna and Professor H. P. Robertson of Princeton University. All of these addresses will be published in the journals of the Society or elsewhere.

The Colloquium Lectures entitled Topics in general analysis were delivered by Professor E. W. Chittenden of the University of Iowa on Tuesday, Wednesday, and Friday mornings and on Thursday afternoon in Emerson Hall. The attendance of 220 establishes a new record. Each lecture was approximately one hour in length. The series will appear in book form. The presiding officers at these lectures were President Lefschetz, VicePresident Norbert Wiener, and Professors E. R. Hedrick and F. S. Woods.

By invitation of the Committee on Program, Professor G. C. Evans of the University of California gave on Saturday morning an address entitled Methods of modern analysis in potential theory. This address will appear in an early issue of this Bulletin.

Besides the meetings mentioned above nine sessions of the Society for the presentation of regular papers were held in Emerson Hall on Tuesday, Thursday, and Saturday mornings, and on Tuesday and Thursday afternoons, the presiding officers be- 
ing Professors G. A. Bliss, E. V. Huntington, H. B. Phillips, M. H. Ingraham, J. L. Walsh, H. F. Blichfeldt, W. C. Graustein, W. F. Osgood, and J. D. Tamarkin.

The Mathematical Association held sessions on Monday morning and afternoon.

The Tercentenary Conference arranged several evening lectures to which mathematicians were invited. Besides that of Professor Hardy given on Monday evening at the joint session of the Society and the Association, there was on Wednesday evening an address by Professor Ettienne Gilson of the Collège de France on Medieval universalism and its present value, on Thursday evening one by Professor Edward Joseph Dent of the University of Cambridge on The historical approach to music, and on Friday evening one by Professor John Dewey of Columbia University on Authority and resistance to social change.

On Thursday evening an informal dinner for the members of the Society and the Association and their guests was held at the Copley-Plaza; 520 people attended this dinner. Professor J. L. Coolidge acted as toastmaster and there were addresses by President J. B. Conant and Dean G. D. Birkhoff of Harvard University, by Professor G. H. Hardy on behalf of the guests, by President Lefschetz of the Society, and by Professor G. A. Bliss.

Professor and Mrs. Harlow Shapley entertained the visiting mathematicians and astronomers at a garden party on Thursday afternoon at the Harvard Observatory residence. Every afternoon tea was served in Phillips Brooks House, the social headquarters for the mathematicians, by the ladies of the Department of Mathematics.

The numerous excursions planned by the Committee on Arrangements added greatly to the pleasure of the meetings and afforded additional opportunities for social intercourse. At the close of the Monday afternoon session there was a short trip in busses around historic Boston, with guides in attendance.

For late Tuesday afternoon two excursions were arranged. One party visited the Massachusetts Institute of Technology to inspect important machines, charts, and the differential analyzer. The second party went to Wellesley College to visit the campus and were received by President M. H. McAfee and Professor M. M. Young; tea was served in Tower Court. 
Wednesday afternoon was devoted to an excursion to Lexington and Concord and to the Wayside Inn, of Longfellow fame, at Sudbury. At the Antiquarian Society building in Concord, Emerson's library was seen. Guides pointed out other spots of interest and a return was made through the Fenway.

On Thursday afternoon guides took parties to visit various Harvard buildings, among them the Faculty Room of University Hall, the University Museum including the Botanical Museum with its display of glass flower models, and the Peabody Museum with its exhibition on the culture of human races.

Excursions were arranged for wives and children of members. On Monday there was a trip through the Yard; on Tuesday to the Isabella Stewart Gardner Museum; on Wednesday to the Tercentenary Exhibition of Furniture and the Decorative Arts and to the Fogg Art Museum; on Thursday to the Boston Museum of Fine Arts; and on Friday to the Undergraduate Houses, the Longfellow House, and Old Cambridge.

The last event of the meetings, in the form of an excursion to the North Shore with a shore dinner at the Adams House in Marblehead, took place late on Saturday morning. On the return trip there was an opportunity, for those who desired, to visit Salem, where guides conducted them to points of interest.

On Thursday afternoon at 1:30 p.m. a panoramic picture of the mathematicians and guests was taken on the steps of Widener Library. This proved to be an interesting feature and approximately 150 copies were sold.

The mathematicians were fortunate in being able to enjoy Harvard's noteworthy exhibits which included mathematical books and a special collection pertaining to the history and scientific activities of the department. Massachusetts Institute of Technology held open house on Tuesday and Thursday for those attending the meetings.

Meals were served in the Harvard Union. Arrangements were made through the Harvard Athletic Association for golf, tennis, and boating and the Harvard Tercentenary Information and Guide Service offered its efficient cooperation to those mathematicians who desired to make individual excursions.

The Council met on Tuesday, September 1, at 8 p.m., in the Library of the Faculty Club. The Board of Trustees held a meeting on Thursday at 12:30 p.m. in the Harvard Union. 
The Secretary announced the election of the following persons to membership in the Society:

Mr. George Richmond Carter, Soil Conservation Service, Marion, Illinois; Miss Ruth M. Culbertson, Highland College, Highland, Kansas;

Dr. Kenneth Smith Ghent, University of Oregon;

Dr. Max Herzberger, Eastman Kodak Research Laboratories, Kodak Park, Rochester, N. Y.;

Dr. Archie Higdon, Boone, Iowa;

Mr. Frederick Gilbert King, Works Progress Administration, New York, N.Y.;

Mr. Fred Kiokemeister, University of Wisconsin;

Mr. Jack Laderman, Bronx, N. Y.;

Mr. Henry Hollis Lansford, Brooklyn College;

Sister Mary Christopher, St. Augustine High School, Kalamazoo, Michigan;

Mr. Francis Fulton Middleswart, Brown University;

Miss Zoé Elizabeth O'Ferrall, Gulf Park College, Gulfport, Mississippi;

Mr. John C. Oxtoby, Harvard University;

Mr. Harwood Rosser, Jr., Jacksonville, Florida;

Dr. Ruth Caroline Stauffer, Harrisburg, Pennsylvania;

Dr. Angus Ellis Taylor, Pasadena, California;

Dr. Stanislaw M. Ulam, Lwow, Poland.

As nominee of the Massachusetts Institute of Technology:

Mr. A. C. Shaeffer, Massachusetts Institute of Technology.

As nominee of Michigan State College:

Mr. Paul L. Dressel, Michigan State College.

The following five institutions were elected to institutional membership in the Society:

Beloit College;

Brigham Young University;

University of Manitoba;

University of Southern California;

Department of Mathematics of Wayne University.

The following appointments by Professor Lefschetz were reported: as an additional member of the Committee on Arrangements for the 1936 Annual Meeting, Professor E. T. Browne; as the Committee on Arrangements for the Gibbs Lecture, Professor B. P. Gill (chairman), Professor W. B. Fite, and Dr. L. A. MacColl; as the reappointed representative of the Society on the Sectional Committee on Standards for Graphic Presentation, Professor W. H. Roever; as the representative of the Society at the inauguration of Grover C. Dillman as President of the Michigan College of Mining and Technology, Houghton, 
Michigan, in connection with the celebration of the fiftieth anniversary of the founding of the college, Professor C. C. Spooner; as the Committee to consider recommendations for the use of the Marion Reilly Fund, Professors D. V. Widder (chairman), G. A. Hedlund, R. E. Langer, J. D. Tamarkin, and T. Y. Thomas.

It was announced that Professor Henry Norris Russell will be the 1936 Gibbs Lecturer, the lecture to be delivered at a joint meeting of the Society and the American Institute of Physics on October 31 in New York City.

A report was presented from Dean L. P. Eisenhart, as chairman of the delegates of the American Mathematical Society to the International Congress for Mathematicians at Oslo, stating that the invitation from the Society to hold the next Congress in this country in 1940 had been unanimously accepted. A committee was constituted to map out a general plan for the Congress, the membership being: Dean L. P. Eisenhart (general chairman), Professors G. A. Bliss, E. W. Chittenden, G. C. Evans, E. R. Hedrick, T. H. Hildebrandt, Einar Hille, J. R. Kline, Marston Morse, P. A. Smith, M. H. Stone, J. D. Tamarkin, J. L. Walsh, and Norbert Wiener.

Announcement was made that by the will of Miss Marion Reilly, former dean of Bryn Mawr College, considerable sums of money have been made and will be made available for the encouragement of research in pure mathematics.

The titles and cross references to abstracts of the papers read at the sessions follow below. The papers were read as follows: papers numbered 1 to 10 in the Section for Foundations on Tuesday morning; papers numbered 11 to 17 in the Section for Analysis on Tuesday morning; papers numbered 18 to 23 in the Section for Topology on Tuesday afternoon; papers numbered 24 to 31 in the Section for Analysis on Tuesday afternoon; papers numbered 32 to 38 in the Section for Algebra on Tuesday afternoon; papers numbered 39 to 43 in the Section for Applied Mathematics on Thursday morning; papers numbered 44 to 50 in the Section for Algebra on Thursday morning; papers numbered 51 to 57 in the Section for Geometry on Thursday morning; papers numbered 58 to 65 on Thursday afternoon; and papers numbered 66 to 68 on Saturday morning; besides, papers num- 
bered 69 to 118 by title. Mr. Robbins was introduced by Dean G. D. Birkhoff, Professor Staniland by Dean R. G. D. Richardson, Dr. Saks by Professor J. D. Tamarkin, Mr. Paxson by Professor A. D. Michal, and Dr. Brenner by Mr. Garrett Birkhoff. Paper number 2 was presented by Dr. Kleene, number 13 by Mr. Jordan, number 27 by Dr. Schoenberg, and number 45 by Professor Ingraham. Papers whose abstract numbers are followed by $t$ were read by title.

1. Extensions of some theorems of Gödel and Church, by Dr. J. B. Rosser. (Abstract No. 42-7-299.)

2. Constructions of formal definitions of functions of ordinal numbers, by Professor Alonzo Church and Dr. S. C. Kleene. (Abstract No. 42-9-380.)

3. Postulates for assertion, conjunction, negation, and equality, by Professor E. V. Huntington. (Abstract No. 42-7-294.)

4. A formal theory of types, by Dr. F. B. Fitch. (Abstract No. 42-9-386.)

5. The algebras of concentric sectors, by Professor Paul Henle. (Abstract No. 42-9-385-t.)

6. Group theory for truth values, by Dr. L. O. Kattsoff. (Abstract No. 42-9-384-t.)

7. The calculus of logical implication, by Dr. A. F. Emch. (Abstract No. 42-9-383-t.)

8. The self-contradictory, by Professor Paul Weiss. (Abstract No. 42-9-382-t.)

9. Two practical problems requiring techniques from symbolic logic, by Mr. E. C. Berkeley. (Abstract No. 42-9-381-t.)

10. An extension of the concept called language, by Mr. Reinhard Korgen. (Abstract No. 42-9-379-t.)

11. Concerning polynomials simultaneously orthogonal on more than one curve, by Professor G. M. Merriman. (Abstract No. 42-7-279.)

12. Stochastic processes depending on a continuously varying parameter, by Dr. J. L. Doob. (Abstract No. 42-7-288.)

13. On convergence of continued fractions, by Mr. J. Q. Jordan and Dr. Walter Leighton. (Abstract No. 42-7-296.)

14. On the convergence of continued fractions, by Dr. Walter Leighton. (Abstract No. 42-9-339.)

15. A problem of Zermelo in the calculus of variations, by Professor W. L. Duren. (Abstract No. 42-7-289.) 
16. On Kakeya's problem (preliminary report), by Professor Morris Marden. (Abstract No. 42-9-343.)

17. Stereographic parameters and pseudo-minimal hypersurfaces. II, by Professor Otto Laporte. (Abstract No. 42-9-338.)

18. General distance functions and the metrization problem, by Dr. Aline H. Frink. (Abstract No. 42-7-291.)

19. Semi-closed sets and collections, by Professor G. T. Whyburn. (Abstract No. 42-7-307.)

20. Branched and folded coverings, by Professor A. W. Tucker. (Abstract No. 42-7-317.)

21. When can a graph be mapped on a torus?, by Dr. Saunders MacLane. (Abstract No. 42-9-341.)

22. Periodic transformations of sets, by Professor W. L. Ayres. (Abstract No. 42-9-319.)

23. Concerning separating transformations which are entirely complete, by Dr. J. F. Wardwell. (Abstract No. 42-9-376.)

24. Functions representable by two Laplace integrals, by Professor D. H. Ballou. (Abstract No. 42-9-321.)

25. An extension of Bernstein's theorem associated with general boundary value problems, by Professor W. H. McEwen. (Abstract No. 42-9-344.)

26. A generalization of the Cauchy-Riemann equations, by Dr. A. E. Taylor. (Abstract No. 42-9-369.)

27. Fourier integrals and metric geometry, by Professor John von Neumann and Dr. I. J. Schoenberg. (Abstract No. 42-9353.)

28. Non-linear difference equations, by Professor W. J. Trjitzinsky. (Abstract No. 42-9-371.)

29. Sufficient conditions by expansion methods for the problem of Bolza in parametric form, by Dr. W. T. Reid. (Abstract No. 42-9-361.)

30. On certain infinite systems of linear equations and an expansion problem of Pincherle, by Dr. P. W. Ketchum. (Abstract No. 42-9-337.)

31. On a class of recurrent sequences, by Mr. H. E. Robbins. (Abstract No. 42-9-362.)

32. On the degrees of the irreducible components of simply transitive permutation groups, by Dr. J. S. Frame. (Abstract No. 42-9318.)

33. On the reduction of positive quaternary quadratic forms 
(preliminary report), by Professor B. W. Jones. (Abstract No. 42-9-336.)

34. Applications of the rational automorphs of $x^{2}+y^{2}+z^{2}$ (preliminary report), by Professor Gordon Pall. (Abstract No. 42-9354.)

35. Arithmetical functions on rings, by Professor Morgan Ward. (Abstract No. 42-9-375.)

36. On algebras which are connected with the simple continuous groups, by Professor Richard Brauer. (Abstract No. 42-9-325.)

37. R-matrices and equivalent networks, by Professor R. S. Burington. (Abstract No. 42-9-327.)

38. Abelian groups without elements of finite order, by Dr. Reinhold Baer. (Abstract No. 42-9-320.)

39. Recurrence relations for the moments of Bernoulli and Poisson frequency distributions, by Mr. John Riordan. (Abstract No. 42-7-298.)

40. A general theorem for rotationally symmetrical optical systems, by Dr. Max Herzberger. (Abstract No. 42-7-293.)

41. On finger print patterns and their singular points, by Dr. Hillel Poritsky. (Abstract No. 42-9-357.)

42. On universally valid stress-strain relations for an elastic solid possessing an energy of deformation, by Professor F. D. Murnaghan. (Abstract No. 42-9-351.)

43. A converse of Poisson's theorem in the theory of probability, by Professor Salomon Bochner. (Abstract No. 42-7-274-t.)

44. Lie groups simply isomorphic with no linear group, by Mr. Garrett Birkhoff. (Abstract No. 42-7-286.)

45. Relative linear sets and similarity of matrices whose elements belong to a division algebra, by Professor M. H. Ingraham and Dr. Margarete C. Wolf. (Abstract No. 42-7-295.)

46. Extension of a multiplicative system to a Boolean ring, by Dr. H. M. MacNeille. (Abstract No. 42-7-316.)

47. On the "singular series" for sums of squares of polynomials, by Professor Leonard Carlitz. (Abstract No. 42-7-313-t.)

48. Representation by generalized polygonal numbers, by Professor L. W. Griffiths. (Abstract No. 42-7-314.)

49. An isomorphism between linear recurring sequences and algebraic rings, by Dr. Marshall Hall. (Abstract No. 42-7-277.)

50. On Waring's problem in algebraic fields, by Professor Hans Rademacher. (Abstract No. 42-9-360.) 
51. Extensions of the four-vertex theorem, by Professor W. C. Graustein. (Abstract No. 42-7-276.)

52. A condition in invariant form for a net without detours, by Professor Robin Robinson. (Abstract No. 42-9-364.)

53. Non-trochoidal rational curves of order $n$ which admit dihedral groups of order $2 n-4$, by Professor R. M. Winger. (Abstract No. 42-7-309.)

54. The binet of quadrics in $S_{3}$, by Professor T. R. Hollcroft. (Abstract No. 42-7-315.)

55. Einstein spaces of class one, by Mr. C. B. Allendoerfer. (Abstract No. 42-7-310.)

56. Analytic affine transformations in euclidean space of $2 n d i$ mensions, by Professor A. E. Staniland. (Abstract No. 42-9367.)

57. On product-continuous sets, by Dr. C. C. Torrance. (Abstract No. 42-9-370.)

58. The four color problem, by Professor Philip Franklin. (Abstract No. 42-7-290.)

59. Locally connected subsets of euclidean n-space, by Professor R. L. Wilder. (Abstract No. 42-7-308.)

60. Orthogonal polynomials on a plane curve, by Professor Dunham Jackson. (Abstract No. 42-9-335.)

61. Minimal surfaces of general topological structure with any nite number of assigned boundaries, by Professor Jesse Douglas. Abstract No. 42-5-239-t.)

62. On convergence factors in restrictedly convergent double series, by Professor C. N. Moore. (Abstract No. 42-9-349.)

63. On products of Nörlund transformations, by Professor L. L. Silverman. (Abstract No. 42-9-366.)

64. On a theorem of Fejér and Riesz, by Dr. E. F. Beckenbach. (Abstract No. 42-9-322-t.)

65. Conformal mapping and Plateau's problem, by Dr. Richard Courant. (Abstract No. 42-9-388.)

66. A general formula for polyhedra with applications to higher dodecahedra and icosahedra, by Mr. A. H. Wheeler. (Abstract No. 42-9-377.)

67. The tensor calculus in a general Riemannian differential geometry, by Professor A. D. Michal. (Abstract No. 42-9-346.)

68. The theory of classes: a modification of von Neumann's system, by Dr. R. M. Robinson. (Abstract No. 42-9-363.) 
69. Sufficient conditions for various degrees of convergence by polynomials, by Professor J. L. Walsh and Dr. W. E. Sewell. (Abstract No. 42-5-236-t.)

70. A problem in Factorisatio Numerorum, by Professor Einar Hille. (Abstract No. 42-7-278-t.)

71. The category and Borel class of certain subsets of $L_{p}$, by Mr. J. C. Oxtoby. (Abstract No. 42-7-281-t.)

72. On some functionals. II, by Dr. Stanislaw Saks. (Abstract No. 42-7-282-t.)

73. Analytic arcs in analytic manifolds, by Professor Walther Mayer and Professor T. Y. Thomas. (Abstract No. 42-7-297-t.)

74. On simple analytic arcs, by Professor T. Y. Thomas. (Abstract No. 42-7-301-t.)

75. On the covering of analytic arcs by coordinate neighborhoods, by Professor T. Y. Thomas. (Abstract No. 42-7-302-t.)

76. Fields of parallel vectors in the large, by Professor T. Y. Thomas. (Abstract No. 42-7-303-t.)

77. Riemann spaces of class one and their characterization, by Professor T. Y. Thomas. (Abstract No. 42-7-304-t.)

78. On an expansion of the inverse Laplace transformation and its application, by Professor R. V. Churchill. (Abstract No. 427-287-t.)

79. Expansions involving a system of differential equations in which the coefficients of the parameters change sign, by Professor C. C. Camp. (Abstract No. 42-7-311-t.)

80. Fuchsian groups and transitive horocycles, by Professor G. A. Hedlund. (Abstract No. 42-9-332-t.)

81. Two-dimensional manifolds and transitivity, by Professor G. A. Hedlund. (Abstract No. 42-9-333-t.)

82. A simplified solution of equation $\Delta y=F(x)$, by Professor I. M. Sheffer. (Abstract No. 42-9-365-t.)

83. A test-ratio test for continued fractions, by Dr. Walter Leighton. (Abstract No. 42-9-340-t.)

84. Complementary manifolds in $L_{p}$ and $l_{p}, 1<p \neq 2$, by Dr. F. J. Murray. (Abstract No. 42-9-352-t.)

85. The integral in abstract linear topological spaces (preliminary report), by Mr. E. W. Paxson. (Abstract No. 42-9-355-t.)

86. On the uniform boundedness of sets of functional transformations between topological spaces, by Professor L. M. Graves. (Abstract No. 42-9-330-t.) 
87. Free continuous groups. II, by Mr. Garrett Birkhoff. (Abstract No. 42-5-241-t.)

88. Lie groups isomorphic in the large with no linear groups, by Mr. Garrett Birkhoff. (Abstract No. 42-5-240-t.)

89. The enumeration of distributive lattices, by $\mathrm{Mr}$. Garrett Birkhoff. (Abstract No. 42-7-273-t.)

90. Linear representability of nilpotent Lie algebras, by $\mathrm{Mr}$. Garrett Birkhoff. (Abstract No. 42-9-323-t.)

91. The normal subgroups of the groups of matrices $\bmod p^{r}$, by Dr. Joel Brenner. (Abstract No. 42-7-275-t.)

92. On the theorem of Jordan-Hölder, by Professor Oystein Ore. (Abstract No. 42-7-280-t.)

93. On generalized Gauss sums, by Professor Leonard Carlitz. (Abstract No. 42-7-312-t.)

94. Hypercomplex numbers and factor sets, by Professor Richard Brauer. (Abstract No. 42-9-324-t.)

95. On algebraic equations of the fifth and sixth degrees, by Professor Richard Brauer. (Abstract No. 42-9-326-t.)

96. On the nth derivative of $f(x)$, by Professor H. S. Wall. (Abstract No. 42-9-374-t.)

97. On hypergroups, by Professor H. S. Wall. (Abstract No. 42-9-373-t.)

98. Concerning uniqueness-bases of finite groups with applications to regular p-groups of class 2, by Dr. Charles Hopkins. (Abstract No. 42-9-334-t.)

99. A normal jorm for the extension from a distributive lattice to a Boolean ring, by Dr. H. M. MacNeille. (Abstract No. 42-9342-t.)

100. Dedekind's $\zeta$-function and Hecke's $\zeta(s, \lambda)$-functions in totally real algebraic fields, by Professor Hans Rademacher. (Abstract No. 42-9-359-t.)

101. Ideal Waring theorem for the polynomial $m\left(x^{3}-x\right) / 6$ $-m\left(x^{2}-x\right) / 2+x$, by Mr. Alvin Sugar. (Abstract No. 42-9368-t.)

102. Rational proofs of the existence of primes in arithmetic sequences, by Dr. J. B. Rosser (National Research Fellow). (Abstract No. 42-5-238-t.)

103. On regular closed curves in the plane, by Professor Hassler Whitney. (Abstract No. 42-9-378-t.)

104. Theory and applications of abstract normal coordinates in 
a general differential geometry, by Professor A. D. Michal and Mr. D. H. Hyers. (Abstract No. 42-9-348-t.)

105. Abstract euclidean spaces. V: Rotations in spaces with indefinite geometrical metric, by Professor A. D. Michal, Dr. I. E. Highberg, and Dr. A. E. Taylor. (Abstract No. 42-9-347-t.)

106. A problem of replacement, by Dr. Hillel Poritsky. (Abstract No. 42-9-356-t.)

107. Thermal stresses in cylindrical tubes, by Dr. Hillel Poritsky. (Abstract No. 42-9-358-t.)

108. A symmetric reduction of the planar three body problem, Professor F. D. Murnaghan. (Abstract No. 42-9-350-t.)

109. Applications of Boolean algebras to general topology, by Professor M. H. Stone. (Abstract No. 42-7-283-t.)

110. Geodesic continua in abstract metric space, by Professor Orrin Frink. (Abstract No. 42-7-292-t.)

111. On boundaries in the plane, by Professor G. T. Whyburn. (Abstract No. 42-7-306-t.)

112. On continua of condensation, by Professor G. T. Whyburn. (Abstract No. 42-7-305-t.)

113. A property of hereditarily continuous curves, by Mr. O. H. Hamilton. (Abstract No. 42-9-331-t.)

114. Mappings and products of cell spaces, by Professor A. W. Tucker. (Abstract No. 42-9-372-t.)

115. Invariant theory of homogeneous contact transformations, by Dean L. P. Eisenhart and Professor M. S. Knebelman. (Abstract No. 42-9-328-t.)

116. Semi-continuity of integrals in the calculus of variations, by Professor E. J. McShane. (Abstract No. 42-9-345-t.)

117. Solvable groups, by Mr. Philip Hall. (Abstract No. 429-389-t.)

118. The web of quadrics, by Professor T. R. Hollcroft. (Abstract No. 42-11-394-t.)

$$
\begin{aligned}
& \text { R. G. D. RICHARDSON, } \\
& \text { Secretary }
\end{aligned}
$$

